\title{
Isolation of a New, Pink, Obligately Thermophilic, Gram- Negative Bacterium (K-2 Isolate)
}

\author{
ROBERT F. RAMALEY, KEITH BITZINGER, ${ }^{1}$ RICHARD M. CARROLL, AND RICHARD B. WILSON \\ Departments of Biochemistry and Pathology, University of Nebraska College of Medicine, Omaha,
} Nebraska 68105

A pink, obligately themophilic $(60 \mathrm{C})$, gram-negative, nonmotile, nonsporeforming, rod-shaped bacterium with a deoxyribonucleic acid base ratio of 64 to 65 $\mathrm{mol} \%$ guanine plus cytosine has been repeatedly isolated from slightly alkaline, man-made and natural thermal aquatic environments. This bacterium $(\mathrm{K}-2$ isolate) does not appear to have been described previously and it has been deposited with the American Type Culture Collection as an unidentified bacterium with the accession no. 27599 .

Prior to 1969 , the bacterium with the highest known optimum growth temperature in laboratory culture was Bacillus stearothermophilus, and the majority of the work on "thermostable" enzymes and other subcellular components was carried out with this gram-positive bacterium (15). However, in 1969, Brock and Freeze (3) reported the isolation of a gram-negative, obligately thermophilic bacterium, Thermus aquaticus, that had an optimum growth temperature of $70 \mathrm{C}$. Since that time, additional gramnegative thermophilic isolates have been obtained that also have optimum growth temperatures of $70 \mathrm{C}$, including Thermus X-1 (14), Thermus thermophilus (13), and Thermomicrobium roseum (10).

The present report describes the physiologic and morphologic properties of a pink, gramnegative, obligately thermophilic bacterium that has a slightly lower "optimum" growth temperature $(60 \mathrm{C})$ but that might eventually be classified as a species of Thermus.

\section{MATERIALS AND METHODS}

Bacterial strains and growth conditions. The "original" K-2 isolate was obtained from a thermally polluted stream on the Indiana University campus in Bloomington, Indiana, as described in the Results section of this paper. This isolate has been deposited in the American Type Culture Collection (ATCC), Rockville, Md., as a pink, obligately thermophilic, unidentified bacterium (K-2 isolate) (ATCC accession no. 27599). Isolate P-P-1 was obtained from the effluent channel of natural hot springs (Poncha Springs) (7, 18) near Poncha City, Colo., in July 1973. Isolates R-P-1 and R-P-2 were obtained from the effluent channel of natural hot springs (Routt Hot Springs) $(7,18) 7$ miles (ca. $11.3 \mathrm{~km}$ ) north of Steamboat Springs, Colo., in August 1973. Thermus aquaticus YT-1 (3) was obtained from T. D. Brock (Depart46514

${ }^{1}$ Present address: Miles Laboratories, Elkart, Ind ment of Microbiology, University of Wisconsin, Madison). Bacillus stearothermophilus strain 10 was obtained from L. L. Campbell (University of Delaware, Newark). Thermus sp. X-1 (14) and Thermomicrobium roseum ATCC 27502 were isolated previously in this laboratory (10). Media and growth conditions were similar to those used for the characterization of Thermus sp. X-1 (14) and Thermomicrobium roseum (10).

Absorbancy spectrum. The absorbancy spectrum of the acetone extract of isolate $\mathrm{K}-2$ was determined with a Cary 15 recording spectrophotometer. The acetone extract was made from exponentially growing cells that had been centrifuged, suspended in $0.05 \mathrm{M}$ potassium phosphate $(\mathrm{pH} 8.0$ ), centrifuged again, suspended in acetone with a Ten-Broeck homogenizer, and centrifuged; the supernatant was used for the absorbancy spectrum. A duplicate sample was placed on a predried, preweighed planchet, dried at $90 \mathrm{C}$, and used to determine the total dry weight.

Phase-contrast photomicrography. A Carl Zeiss RA phase microscope with a $\times 100$ Neofluor objective was used for all microscopy observation. Photomicrography was performed with a Zeiss camera with Kodak Monochrome film (SO-410 ESTAR-AH base 135-36; Eastman Kodak Co., Rochester, N.Y.).

Scanning electron microscopy. A segment of agar carrying a single 48-h-old colony of the K-2 isolate was cut out and fixed in modified Zamboni fixative (16) for several hours. The Zamboni fixative was modified by dilution to $50 \%(\mathrm{vol} / \mathrm{vol})$ with water and addition of glutaraldehyde to a final concentration of $1 \%(\mathrm{vol} / \mathrm{vol})$. A smear from a similar colony was made on a glass cover slip and fixed in the same manner. Postfixation was carried out in 1\% osmium tetroxide in $0.1 \mathrm{M}$ phosphate buffer ( $\mathrm{pH}$ 7.4) for $1 \mathrm{~h}$. The osmium was then cross-linked by treating the specimens with thiocarbohydrazide (saturated solution in water) for $20 \mathrm{~min}$ (11) and treating them again with osmium for $1 \mathrm{~h}$. This treatment did not completely prevent electrostatic charging in the scanning electron microscope, so the specimens were subsequently coated with successive thin layers of carbon and gold in a vacuum evaporator. The speci- 
mens were viewed in a scanning electron microscope at $20 \mathrm{kV}$. The original micrographs were taken on Polaroid 55 PN film.

DNA base ratio. Deoxyribonucleic acid (DNA) was isolated by the method of Marmur (12). Treatment with lysozyme and complete homogenization of the bacteria after addition of the detergent and phenol with a Ten-Broeck homogenizer were necessary to effect complete release of the DNA from this and other similar gram-negative, thermophilic bacteria. The buoyant density of the different K-2-type DNAs in cesium chloride was determined by density gradient ultracentrifugation as reported previously with Escherichia coli bacteriophage T2 as reference DNA (14).

Chemicals. Yeast extract, tryptone, and agar were obtained from Difco Laboratories, Detroit, Mich. The biochemicals were obtained from the Sigma Chemical Co., St. Louis, Mo. All other chemicals were from the Fisher Scientific Co. Pittsburgh, $\mathrm{Pa}$. All water used was tap-distilled water which passed through a mixed-bed ion-exchange resin. In some cases, doubly glass-distilled water was used, but no significant difference in results was observed.

\section{RESULTS}

Isolation of the K-2 isolate. The K-2 isolate was isolated in 1972 from thermally polluted streams on the Indiana University campus in Bloomington, Ind. Isolates resembling the K-2 isolate were obtained from natural hot springs in Colorado during the summer of 1973. The area on the Indiana University campus that yielded the highest number of K-2-type isolates (30\% of the total number of thermophilic bacteria) was in the lower portion of a thermal gradient that was caused by the constant discharge of hot water $(90 \mathrm{C})$ from a pipe alongside a stone bridge across the Jordan River north of Jordan Avenue. This area is close to station $30 \mathrm{~b}$ previously investigated by Brock and Yoder (4). The Colorado hot spring thermal gradients that yielded the highest numbers of K-2-type isolates were at Poncha Hot Springs $(7,18)$ (Poncha Spring, Colo.) and Routt Hot Springs $(7,18)$ (7 miles [ca. $11.3 \mathrm{~km}$ ] north of Steamboat Springs). Neither of these springs has detectable levels of sulfide (7). Other springs, such as Waunita Hot Springs east of Gunnison, Colo., that have a higher level of sulfide $(7,18)$ did not yield any of the K-2-type isolates.

It is interesting that the K-2-type isolate is most often found in partially shaded thermal gradients in which the bacterial mat has been disturbed and is regrowing, and not in highlight areas such as the effluent channels of slightly alkaline hot springs at Yellowstone $\mathrm{Na}$ tional Park.

Properties of the K-2 and K-2-type isolates. (i) Optimum growth temperature. All of the isolates obtained to date have an optimum growth temperature of $60 \mathrm{C}$ (Fig. 1) when grown in $0.1 \%$ (wt/vol) yeast extract- $0.1 \%$ (wt/vol) tryptone in Castenholz salts at $\mathrm{pH}$ 7.6. The K-2 isolate only grows in a slightly alkaline medium ( $\mathrm{pH}$ optimum of 7.6 to 7.8 ). In static tube cultures of the K-2 isolate, visible growth on the surface of the liquid medium can be observed after 2 weeks at $80 \mathrm{C}$, the apparent upper temperature limit of growth for the K-2 isolate.

(ii) Absorption spectra of the K-2 and K2-type isolates. Figure 2 shows the absorption spectrum of an acetone extract of the K-2 isolate. All of the K-2-type isolates examined have

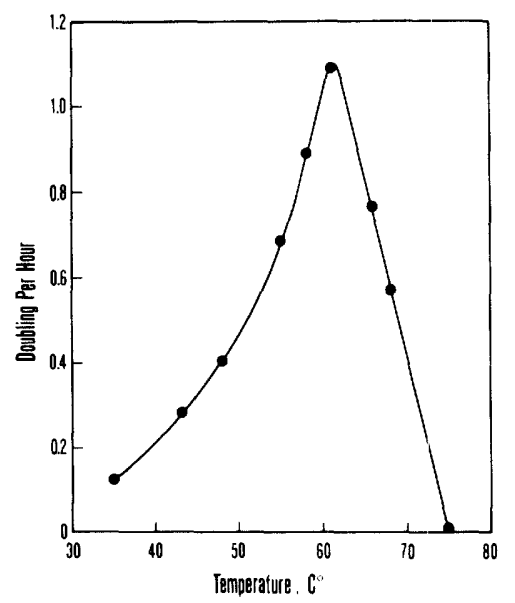

Fig. 1. Effect of temperature on the growth rate of the K-2 isolate.

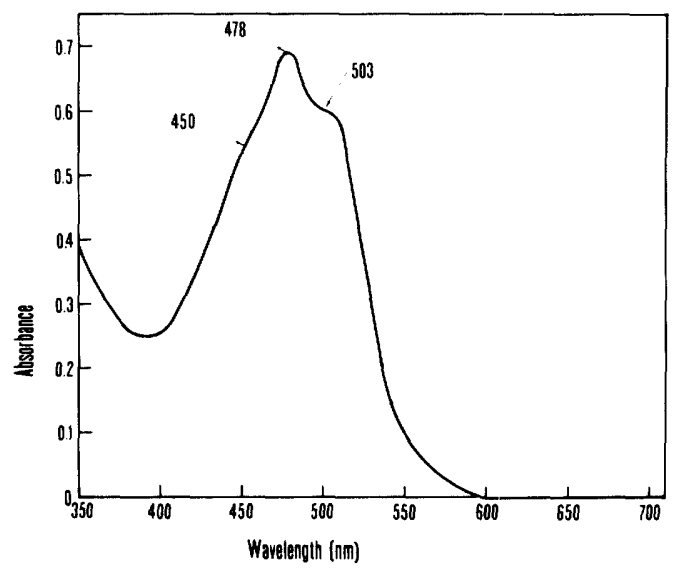

FIG. 2. Absorption spectrum for the acetone extract of the K-2 isolate. The acetone extract (from 50 mg-eq dry weight of cells per $\mathrm{ml}$ of acetone) was prepared from exponentially growing cells of the K-2 isolate. 
the same pink-to-light red colonial pigmentation and absorption spectrum. The absorption spectrum is quite distinct from that of the palepink, pleomorphic, thermophilic bacterium Thermomicrobium roseum isolated from Yellowstone National Park (10). The pink pigmentation of the K-2 isolate is not water soluble and is bound firmly to the isolated cell membrane. This pigmentation is presumably due to carotenoids, which are currently being investigated by J. J. Cooney of the University of Dayton, Dayton, Ohio. There is no present evidence that light is required for pigment production.

(iii) DNA base ratios of the K-2 and K-2type isolates. Table 1 shows the DNA base ratios of the $\mathrm{K}-2$ isolate (Bloomington, Ind.), the P-P-1 isolate (Poncha Hot Springs, Colo.), and the R-P-1 and R-P-2 isolates (Routt Hot Springs, Colo.). The guanine plus cytosine $(\mathrm{G}+\mathrm{C})$ contents of the DNAs of all of the isolates are similar, with an average value of 64.4 $\pm 0.6 \mathrm{~mol} \%$, as determined by $E$. Carusi of the Creighton Medical School in Omaha, Neb. Thus, the DNA base ratios of the $\mathrm{K}-2$ and $\mathrm{K}-2$ type isolates are very similar to those of other gram-negative thermophilic bacteria found in slightly alkaline thermal aquatic environments, e.g., Thermus X-1 (64 to $65 \mathrm{~mol} \% \mathrm{G}+\mathrm{C}$ ) (13; unpublished data), Thermus aquaticus (65.4 to $67.4 \mathrm{~mol} \% \mathrm{G}+\mathrm{C}$ ) (3), and Thermomicrobium (64.3 mol\% $\mathrm{G}+\mathrm{C})(10)$.

(iv) Morphology of the K-2 and K-2-type isolates. The isolates all have a similar colonial and cellular morphology. Figure 3 shows a phase-contrast photomicrograph of the R-P-1 isolate from Routt Hot Springs, and Fig. 4A shows a scanning electron micrograph of the peripheral surface of a colony of the original K2 isolate. Figure $4 \mathrm{~B}$ shows a scanning electron micrograph of some individual cells of the K-2 isolate on the agar surface, and Fig. $4 \mathrm{C}$ shows some single cells smeared onto a cover slip. The fixative method used for these cells produced very little shrinkage.

Repeated measurement of the different isolates under phase-contrast observation with an ocular micrometer calibrated with a stage micrometer gave an average cell diameter for the $\mathrm{K}-2$ isolate of between 0.7 and $0.8 \mu \mathrm{m}$ and an average length of between 5 and $8 \mu \mathrm{m}$. Similar measurements of a Thermus isolate give a slightly smaller diameter $(0.6$ to $0.8 \mu \mathrm{m})$ and filamentous forms up to $100 \mu \mathrm{m}$ (3) in length, depending on cultural conditions and the temperature employed.

(v) Growth requirements of the K-2 isolate. Table 2 lists some of the media tested that supported the growth of the K-2 isolate in static culture. A number of different complex carbon sources at low concentration can serve for the growth of the K-2 isolate. Although some growth can be obtained with glutamate as the sole carbon source and with other simple minimal media in liquid culture, the K-2 isolate will not grow upon repeated transfers on glutamate agar, suggesting additional growth factor requirements beyond those of Thermus. The K-2 isolate showed no nitrate reductase activity and, like Thermus aquaticus, cannot use nitrate as a significant nitrogen source. In contrast, Thermus $\mathrm{X}-1$ has a very active nitrate reductase (R. Ramaley and $R$. Carroll, unpublished data).

\section{DISCUSSION}

Table 3 presents a summary of some of the properties of the K-2 isolate in comparison with other thermophilic bacteria. In the practical identification of the K-2 isolate, its morphology, obligate thermophily, and characteristic pink-to-red pigmentation make it quite easy to identify. However, its taxonomic relationship with the other thermophilic, gram-negative iso-

TABLE 1. DNA base ratios of the K-2 and K-2-type isolates

\begin{tabular}{|c|c|c|c|c|}
\hline Strain no. & Source & $\begin{array}{l}\text { DNA bouyant } \\
\text { density }\left(\mathrm{g} / \mathrm{cm}^{3}\right)\end{array}$ & $\mathrm{Mol} \% \mathrm{G}+\mathrm{C}^{a}$ & $\begin{array}{l}\text { Ultracentrifugation } \\
\text { performed by }\end{array}$ \\
\hline $\mathrm{K}-2$ & Bloomington, Ind. & 1.722 & 63.8 & L. Prather \\
\hline $\mathrm{K}-2$ & Bloomington, Ind. & 1.723 & 64.3 & E. Carusi \\
\hline P-P-1 & Poncha Hot Springs, Colo. & 1.723 & 64.3 & E. Carusi \\
\hline R-P-1 & Routt Hot Springs, Colo. & 1.724 & 65.3 & E. Carusi \\
\hline R-P-2 & Routt Hot Springs, Colo. & 1.722 & 63.8 & E. Carusi \\
\hline
\end{tabular}

a The average and standard deviation for all the $\mathrm{G}+\mathrm{C}$ values shown is $64.3 \pm 0.6 \mathrm{~mol} \%$. The average and standard deviation for the last four determinations is $64.4 \pm 0.6 \mathrm{~mol} \%$. 


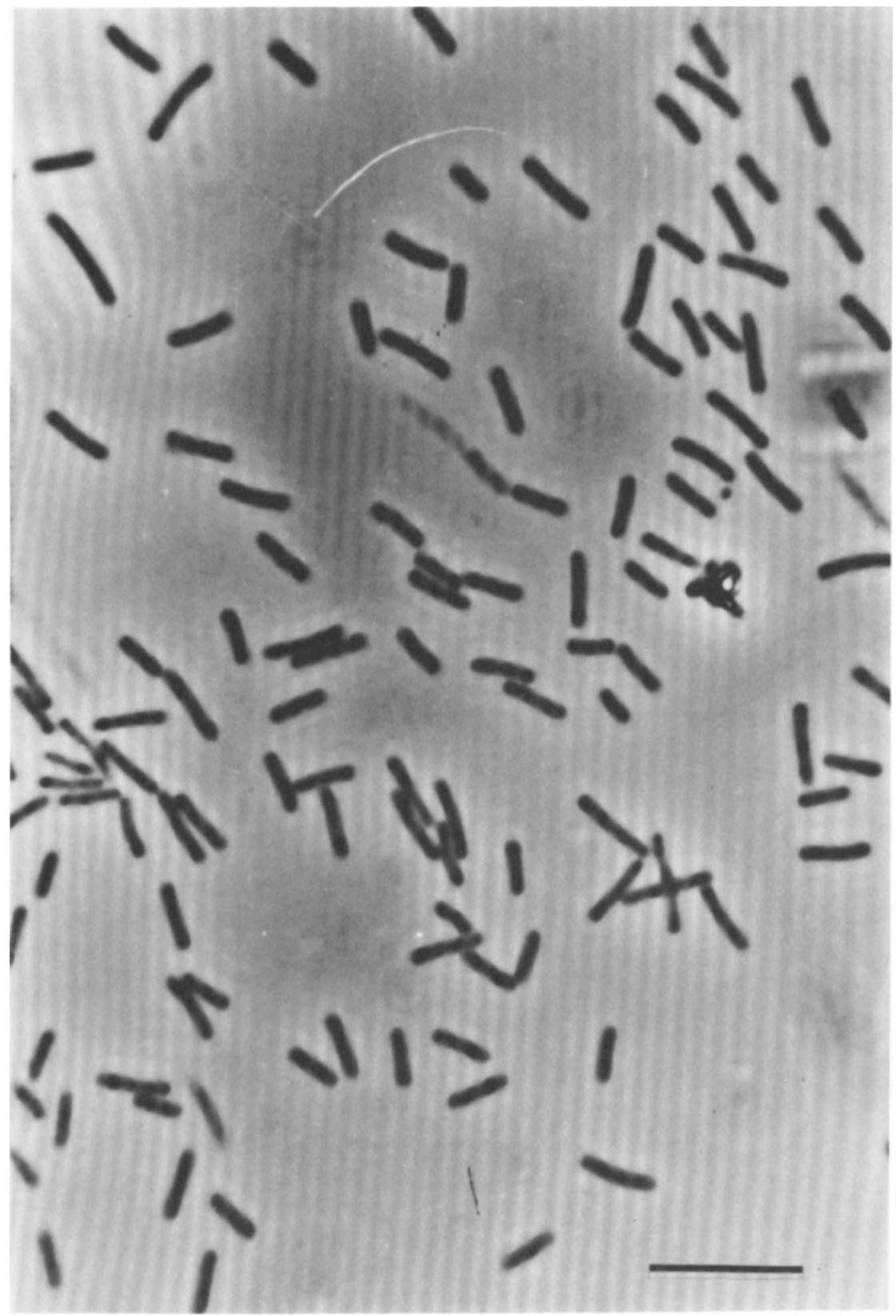

FIG. 3. Phase-contrast photomicrographs of the isolate from Routt Hot Springs (R-P-1). Marker bar indicates $10 \mu \mathrm{m}$.

lates (Thermus, etc.) that are also found in slightly alkaline thermal environments is quite unclear. One possibility would be to create a new genus for the K-2 isolate, as was done for Thermus aquaticus (3), Thermomicrobium (10), Sulfolobus (2), and Thermoplasma (6). This is, perhaps, the least satisfactory solution considering the continuing isolation of physiologically similar thermophilic gram-negative isolates and the eventual confusion that would result from creating an excessive number of genera for them. Premature assignment as to genus and species have already confused the thermophilic isolates of Heinen now that it has 
been shown that these isolates are sporeforming bacteria $(8,9)$.

A second possibility would be to place K-2 in a separate species in an existing genus such as Thermus. The base ratio of the K-2 DNA falls within the range designated for Thermus. Like Thermus strains, it only grows on dilute organic media, is an obligate aerobe, and produces only acid from carbohydrates. It resembles Thermus strains morphologically although it does not seem to form the characteristic long, filamentous cells. However, there are some yellow Thermus isolates that have very transulent, spreading colonies and that do not seem to form the long filaments (13; unpublished data) of the type species Thermus aquaticus.

According to the diagnostic keys in the 8th edition of Bergey's Manual of Determinative Bacteriology (5), the K-2 isolate keys out to Thermus, except for its optimum growth temperature ( 60 versus 70 to $72 \mathrm{C}$ for Thermus) and its pigmentation (pink versus nonpigmented to yellow-orange for Thermus). It is entirely possible that the $\mathrm{K}-2$ isolate is a member of a species of Thermus. However, to place it in a new species of Thermus would also require a broad- ening of the description of Thermus with respect to optimum temperature and pigmentation.

Another alternative would be to place the K2 isolate in one of the species of Flavobacterium with a high $\mathrm{G}+\mathrm{C}$ value since "... one of the functions of this genus has always been to be used rather nondiscriminantly as a category for pigmented, aerobic rods that are usually gramnegative and anaerogenic in carbohydrate-containing medium. This use of Flavobacterium as a category of taxonomic convenience is precisely what the originators of the genus intended" $(\mathrm{O}$. B. Weeks, personal communication).

The K-2 isolate keys into the genus Flavobacterium as a second possibility, and at least one red-pigmented marine bacterium has been assigned to Flavobacterium (5). However, Oshima and Imahori (13) removed a thermophilic organism from the genus Flavobacterium and placed it in Thermus.

Since the K-2 isolate and other gram-negative, thermophilic bacteria (Thermus strains, etc.) are being used increasingly in this and other laboratories (3) for comparative biochemi-

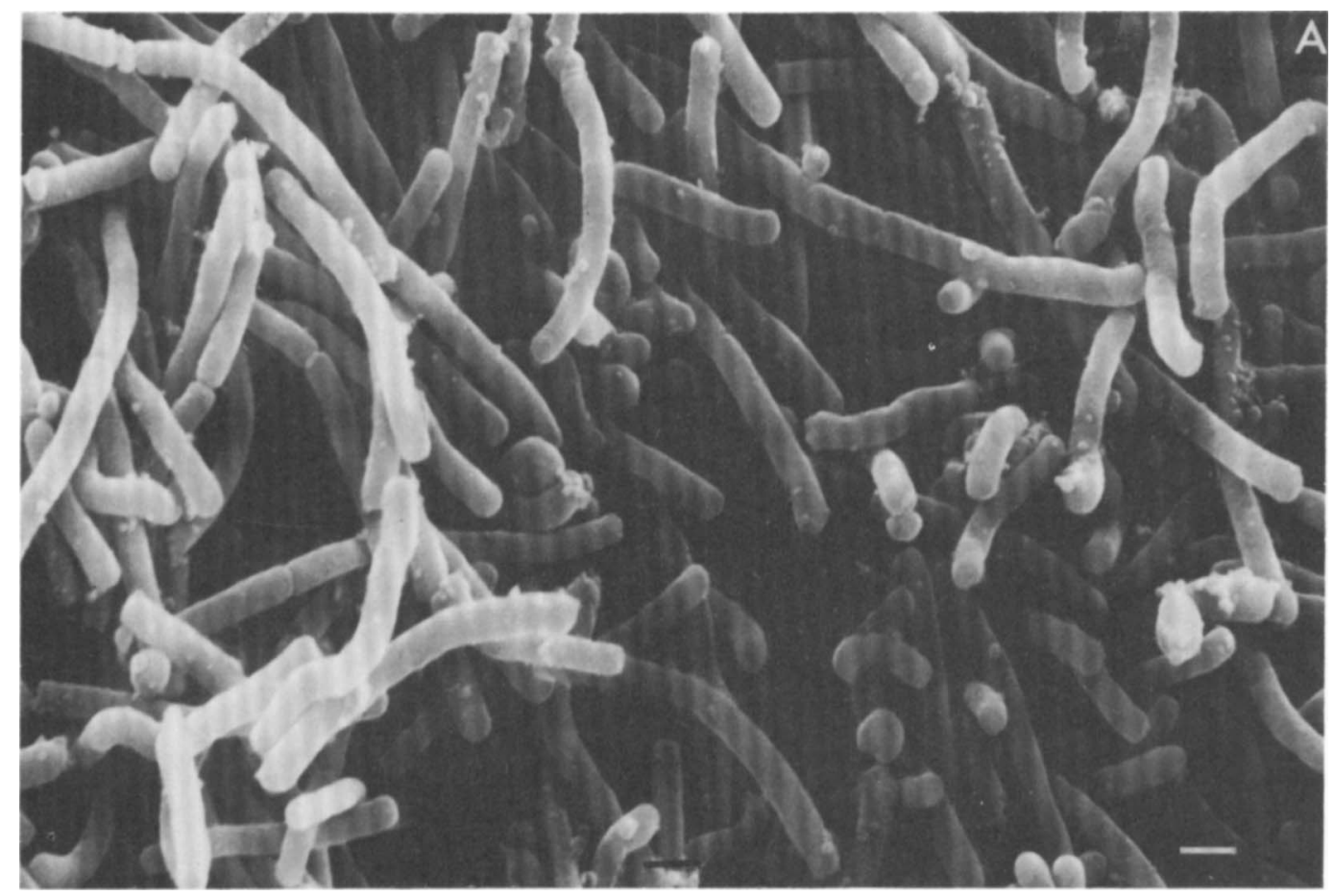

FIG. 4. Scanning-electron photomicrographs of the K-2 isolate. (A) Surface of a young (48-h-old) colony; $(B)$ isolated cells on the agar surface; $(C)$ isolated cells in a smear made on a glass cover slip. The marker bar indicates $1 \mathrm{\mu m}$. 

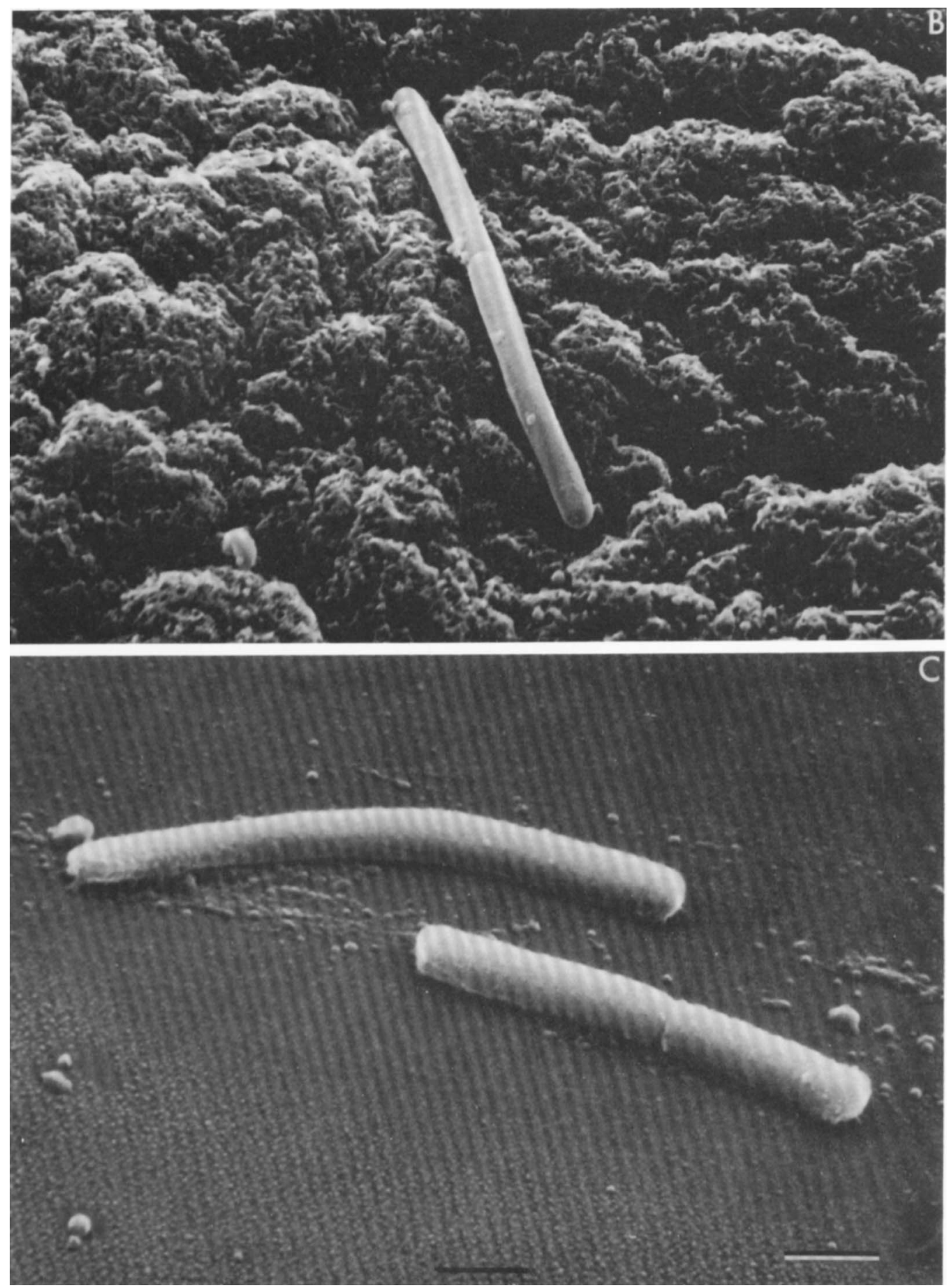

FIg. $4 B$ and $C$ 
cal studies, it is important that the different isolates be characterized and identified so far as possible. The K-2 isolate appears to belong to a new species, but assignment to any of the cur-

TABlE 2. Media supporting growth of the $K-2$ isolate $^{a}$

\begin{tabular}{lcc}
\hline $\begin{array}{c}\text { Compounds } \\
(0.1 \%, \text { wt/vol }) \\
\text { added to } \\
\text { basal salts } \\
\text { media }\end{array}$ & \multicolumn{2}{c}{$\begin{array}{c}\text { Growth in basal } \\
\text { salts media }\end{array}$} \\
\cline { 2 - 3 } & $\begin{array}{c}\text { Castenholz } \\
\text { (nitrate) }\end{array}$ & $\begin{array}{c}\text { Allen (10) } \\
\text { (ammonia) }\end{array}$ \\
\hline Yeast extract plus tryptone & ++ & ++ \\
Yeast extract & ++ & ++ \\
Tryptone & + & +- \\
Peptone & +- & ++ \\
Casein hydrolysate & - & - \\
Tryticase soy & + & ++ \\
Nutrient broth & + & ++ \\
Mannitol & + & + \\
Glutamate & +- & + \\
\hline
\end{tabular}

${ }^{a}++$, Heavy growth; + , light to moderate growth; +-, trace; - , no growth. No growth with fructose, glucose, glycerol, succinate, acetate, or citrate under the conditions tested after 1 week. All media had an initial $\mathrm{pH}$ of 7.8 . rently recognized genera is difficult. Thus, pending a revision of the genus Thermus as new Thermus isolates are obtained (5), the K-2 isolate is referred to simply as a pink, obligately thermophilic, unidentified bacterium. A culture of this strain has been deposited in the American Type Culture Collection under the number 27599. Studies of the comparative properties of some of the enzymes and other cellular components of the K-2 isolate and of the ecological distribution of the K-2 isolate will be published elsewhere.

\section{ACKNOWLEDGMENTS}

This work was supported by National Science Foundation grant GB-36931. The initial isolation and preliminary characterization of the K-2 isolates were made while the three senior authors were associated with the Department of Microbiology at Indiana University, Bloomington. The studies of the Colorado hot springs were conducted from the Rocky Mountain Biological Laboratory at Crested Butte, Colo., with the assistance of Alan Ramaley. We would like to thank E. Carusi (Creighton Medical School, Omaha, Neb.) for the determination of DNA base ratios and Linda Malick (Eppley Institute for Research in Cancer, University of Nebraska Medical Center, Omaha) for the processing of samples for the scanning electron microscope.

\section{REPRINT REQUESTS}

Address reprint request to: Dr. Robert F. Ramaley, Department of Biochemistry, University of Nebraska, College of Medicine, Omaha, Neb. 68105.

\section{LITERATURE CITED}

1. Brock, T. D. 1970. High temperature systems. Annu.

TABLE 3. Summary of the properties of the K-2 isolate and other thermophilic bacteria found in slightly alkaline thermal environments

\begin{tabular}{|c|c|c|c|c|c|}
\hline Property & $\mathrm{K}-2$ isolate & $\begin{array}{l}\text { Thermomicro- } \\
\text { bium roseum }\end{array}$ & $\begin{array}{l}\text { Thermus } \\
\text { aquaticus } \\
\text { YT-1 }\end{array}$ & Thermus X-1 & $\begin{array}{l}\text { Bacillus stearother- } \\
\text { mophilus } 10\end{array}$ \\
\hline Colony color & Pink & Pale pink & Yellow & Cream & Cream to brown \\
\hline $\begin{array}{l}\text { Optimum growth temp } \\
\text { (C) }\end{array}$ & 60 & $70-75$ & 70 & 70 & $60-65$ \\
\hline Generation time $^{a}(\mathrm{~min})$ & 50 & 360 & $60-70$ & $50-60$ & 12 \\
\hline $\mathrm{pH}$ range for growth ${ }^{a}$ & $7.5-10$ & $8.0-10$ & $7.5-9.0$ & $7.5-10$ & $5.0-9.0$ \\
\hline Cell morphology & Thin rods & $\begin{array}{l}\text { Short, pleomorphic } \\
\text { rods }\end{array}$ & Thin rods & Thin rods & $\begin{array}{l}\text { Sporeforming, wider } \\
\text { rods }\end{array}$ \\
\hline $\begin{array}{l}\text { Growth on standard nutri- } \\
\text { ent } \text { agar }^{b}\end{array}$ & No & No & No & No & Yes \\
\hline $\begin{array}{c}\text { Growth } \\
\text { agar }^{b}\end{array}$ on glutamate & No & Yes & Yes & Yes & Yes \\
\hline $\begin{array}{l}\text { Production of nitrite from } \\
\text { nitrate }\end{array}$ & No & No & $\mathrm{No}^{r}$ & Yes & Yes \\
\hline
\end{tabular}

\footnotetext{
" Determined from turbidity increase as described in the text.

${ }^{b}$ Production of single, isolated colonies away from initial streak. Some of the original medium was usually carried over in the initial streak area and, combined with the high number of organisms, may have led to apparent growth.

"Very low level of nitrite believed not to be significant.
} 
Rev. Ecol. Syst. 1:191-220.

2. Brock, T. D., K. M. Brock, R. T. Belly, and R. L. Weiss. 1972. Sulfolobus: a new genus of sulfur oxidizing bacteria living at low $\mathrm{pH}$ and high temperature. Arch. Mikrobiol. 84:54-68.

3. Brock, T. D., and H. Freeze. 1969. Thermus aquaticus gen. n. and sp. n., a nonsporulating extreme thermophile. J. Bacteriol. 98:289-297.

4. Brock, T. D., and I. Yoder. 1971. Thermal pollution of a small river by a large university: bacterial studies. Proc. Indiana Acad. Sci. 80:183-188.

5. Buchanan, R. E., and N. E. Gibbons (ed.). 1974. Bergey's manual of determinative bacteriology, 8th ed. The Williams \& Wilkins Co., Baltimore.

6. Darland, G., T. D. Brock, W. Samsonoff, and S. F. Conti. 1970. A thermophilic, acidophilic mycoplasma isolated from a coal refuse pile. Science 170:14161418.

7. George, R. D., H. A. Curtis, O. C. Lester, J. K. Crook, J. B. Yeo, and others. 1920. Mineral waters of Colorado. Bulletin 11. Colorado Geological Survey, Denver.

8. Heinen, U. J., and W. Heinen. 1972. Characteristics and properties of a caldo-active bacterium producing extracellular enzyme and two related strains. Arch. Mikrobiol. 82:1-23.

9. Heinen, W. 1971. Growth conditions and temperaturedependent substrate specificity of two extremely thermophilic bacteria. Arch. Mikrobiol. 76:2-17.

10. Jackson, T. J., R. F. Ramaley, and W. G. Meinschein. 1973. Thermomicrobium, a new genus of extremely thermophilic bacteria. Int. J. Syst. Bacteriol. 23:28 36 .

11. Kelley, R. O., R. A. R. Dekker, and J. G. Bluemink. 1973. Ligand-mediated osmium binding: its application in coating biological specimens for scanning electron microscopy. J. Ultrastruct. Res. 49:254-258.

12. Marmur, J. 1961. A procedure for the isolation of deoxyribonucleic acid from micro-organisms. J. Mol. Biol. 3:208-218.

13. Oshima, T., and K. Imahori. 1974. Description of Thermus thermophilus (Yoshida and Oshima) comb. nov., a nonsporulating, thermophilic bacterium from a Japanese thermal spa. Int. J. Syst. Bacteriol. 24:102112.

14. Ramaley, R. F., and J. Hixson. 1970. Isolation of a nonpigmented thermophilic bacterium similar to Thermus aquaticus. J. Bacteriol. 103:527-528.

15. Singleton, R., and R. E. Amelunxen. 1973. Proteins from thermophilic microorganisms. Bacteriol. Rev. $37: 320-342$.

16. Stefanini, M., C. DeMartino, and L. Zamboni. 1967. Fixation of ejaculated spermatozoa for electron microscopy. Nature (London) 216:173-174.

17. Ulrich, J. R., G. A. McFeters, and K. L. Temple. 1972 Induction and characterization of $\beta$-galactosidase in an extreme thermophile. J. Bacteriol. 110:691-698.

18. Waring, G. A., R. R. Blankenship, and R. Bentall. 1965. Thermal springs of the United States and other countries of the world: a summary. U.S. Geological Survey Report, Department of the Interior. U.S. Government Printing Office, Washington, D.C. 